\title{
Does plantation forestry restore biodiversity or create green deserts? A synthesis of the effects of land-use transitions on plant species richness
}

\author{
Leah L. Bremer • Kathleen A. Farley
}

Received: 12 March 2010/Accepted: 20 October 2010/Published online: 11 November 2010

(C) The Author(s) 2010. This article is published with open access at Springerlink.com

\begin{abstract}
Plantations are established for a variety of reasons including wood production, soil and water conservation, and more recently, carbon sequestration. The effect of this growing land-use change on biodiversity, however, is poorly understood and considerable debate exists as to whether plantations are 'green deserts' or valuable habitat for indigenous flora and fauna. This paper synthesizes peer-reviewed articles that provide quantitative data on plant species richness in plantations and paired land uses, most often representative of preplantation land cover. The results of this synthesis suggest that the value of plantations for biodiversity varies considerably depending on whether the original land cover is grassland, shrubland, primary forest, secondary forest, or degraded or exotic pasture, and whether native or exotic tree species are planted. The results of this study suggest that plantations are most likely to contribute to biodiversity when established on degraded lands rather than replacing natural ecosystems, such as forests, grasslands, and shrublands, and when indigenous tree species are used rather than exotic species. These findings can help guide afforestation and reforestation programs, including those aimed at increasing terrestrial carbon sequestration.
\end{abstract}

Keywords Afforestation - Reforestation - Plantations · Land-use change - Biodiversity · Plant diversity $\cdot$ Species richness $\cdot$ Carbon sequestration

\section{Abbreviations \\ FAO Food and Agricultural Organization \\ SR Species richness}

Electronic supplementary material The online version of this article (doi:10.1007/s10531-010-9936-4) contains supplementary material, which is available to authorized users.

\section{L. Bremer $(\bowtie) \cdot$ K. A. Farley}

Department of Geography, San Diego State University, 5500 Campanile Drive,

San Diego, CA 92182-4493, USA

e-mail: lbremer@rohan.sdsu.edu

\section{L. Bremer}

Department of Geography, 1832 Ellison Hall, U.C. Santa Barbara,

Santa Barbara, CA 93106-4060, USA 


\section{Introduction}

Deforestation continues at a rate of 13 million hectares per year with devastating effects on biodiversity, particularly in the tropics. At the same time, afforestation and reforestation have led to an increase in forest and tree cover in some areas, lowering the global net forest loss to 7.3 million hectares per year (Bass 2004; Hecht et al. 2006; Liu et al. 2008). A subset of this forest resurgence includes the 139.1 million hectares of timber plantations that continue to expand at a rate of 2.6 million hectares per year (FAO 2006). As plantations become an increasingly ubiquitous land use, intense debate surrounds the extent to which these anthropogenic forests protect or degrade biodiversity (Norton 1998; Brockerhoff et al. 2008). Improved understanding of how plantations and other "working landscapes" affect biodiversity and other ecosystem services is critical to forming socially and ecologically sustainable land-use policies (Goldman et al. 2008).

While many researchers have found low levels of biodiversity in plantations (Matthews et al. 2002; Barlow et al. 2007a; Makino et al. 2007), other studies suggest that plantations can play an important role in biodiversity conservation and restoration of forest species (Hartley 2002; Cusack and Montagnini 2004; Carnus et al. 2006; Brockerhoff et al. 2008), particularly when management aims to balance environmental and economic goals (Brockerhoff et al. 2001; Hartley 2002; Brockerhoff et al. 2008). Enhanced biodiversity outcomes are expected with plantations that utilize indigenous tree species (Pejchar et al. 2005; Carnus et al. 2006; Stephens and Wagner 2007; Brockerhoff et al. 2008), mixed species (Michelsen et al. 1996; Hartley 2002), broadleaf rather than conifers (Aubin et al. 2008) and longer rotation lengths (Ogden et al. 1997; Brockerhoff et al. 2003), and where they replace pastures with little remnant native vegetation (Felton et al. 2010). Some plantations also provide critical habitat for endangered species, increasing the need to integrate conservation goals into management strategies (Brockerhoff et al. 2001; Pejchar et al. 2005; Arrieta and Suarez 2006). Other researchers and land managers point to the utility of plantations as wildlife corridors, which, from a landscape ecology standpoint, may play an important role in sustainable development (Hobbs et al. 2003; Lindenmayer and Hobbs 2004). Still others suggest that, in terms of conserving species diversity, plantations may be a "lesser-evil" alternative to agriculture or urban development (Carnus et al. 2006; Newmaster et al. 2006; Brockerhoff et al. 2008).

Disagreement over the environmental value of plantations stems, in part, from the heterogeneity of plantations and the land covers they replace. An evaluation of the sustainability of plantations as a land use requires an evaluation of the changes and tradeoffs in ecosystem goods and services associated with plantations in comparison with alternative land uses (Mather 1992; Rudel et al. 2005; Carnus et al. 2006; Farley 2007; Brockerhoff et al. 2008). In presenting plantations as part of the "forest transition," where periods of forest decline are followed by spontaneous and induced forest re-growth, Rudel et al. (2005, p. 23) suggest that "plantations do little to conserve biodiversity, but they do sequester carbon and conserve soil, so governments should place a high priority on promoting them." In reality, however, environmental outcomes of plantations, including effects on soil carbon (Bashkin and Binkley 1998; Guo and Gifford 2002; Farley et al. 2004), on water quality and quantity (Farley et al. 2005; Van Dijk and Keenan 2007; Farley et al. 2008), and on biodiversity (Hartley 2002; Carnus et al. 2006; Stephens and Wagner 2007; Brockerhoff et al. 2008; Buscardo et al. 2008) vary greatly depending upon the characteristics of both the plantations and of the previous land uses.

Synthesizing individual case studies and evaluating the patterns that emerge across cases can help to explain this diversity of outcomes observed with plantation 
establishment. In a global review of biodiversity of multiple taxa in plantations compared to pasture lands, Felton et al. (2010) found significantly higher amphibian and reptile richness in plantations, but found no significant differences in species richness of other taxa, including plants, mammals, and invertebrates in plantations versus pasture lands. Pointing to "unexplained heterogeneity between studies," Felton et al. (2010, p. 545) caution against "general statements about the inherent biodiversity value of diverse and broadly-defined land uses." This conclusion emphasizes the importance of scrutinizing differences within the broad categories of plantations and pasture lands, including whether plantations use exotic or native species, proximity to native vegetation, and prior land-use history. While, in addition to Felton et al.'s (2010) synthesis, several other studies summarize biodiversity and plantation case studies (Carnus et al. 2006; Stephens and Wagner 2007; Brockerhoff et al. 2008), there has yet to be a synthesis of quantitative changes in biodiversity with plantation establishment across a range of paired land covers and plantation types.

Accordingly, this paper synthesizes existing quantitative data available on plant richness in plantations (including those using native and exotic species) in comparison with alternative land covers (categorized as primary forest, secondary forest, shrubland, grassland, and degraded or exotic pasture) in order to inform land-use policy and stimulate further research. The focus is on between species diversity using plant species richness (including total, exotic, and native species richness) as a proxy for biodiversity. While this will not necessarily reflect biodiversity of other taxa, understory vegetation is considered to be a good predictor of faunal diversity (Humphrey et al. 1999). Moreover, plants are the basis of the food chain and contribute to important ecosystem services including climate regulation, water purification, and pollination (Daily 1997; Goldman et al. 2008). As such, an evaluation of plantations and plant diversity provides valuable information on the effects on vegetation with implications for wider ecosystem services and the faunal diversity they support.

Specifically, the research questions addressed in this synthesis are:

- What is the relationship between the type of land-use transition (grassland to plantation, shrubland to plantation, primary forest to plantation, secondary forest to plantation, and exotic or degraded pasture to plantation) and the effects of plantation establishment on plant biodiversity?

- How do plantation age, plantation species, and plantation location and management affect plant biodiversity where plantations are established?

\section{Methods}

We compiled peer-reviewed articles that quantified plant biodiversity through measures of species richness, and percent native or specialist/narrow/endemic species. Literature searches were performed using the electronic databases Web of Science, Inspec, BIOSIS Previews, and Science Direct with search terms including: "biodiversity and (plantations or planted forests or afforestation)," and "species richness and (plantations or planted forests or afforestation)." Additional case studies were found through reviewing references in relevant publications including reviews on plantations and biodiversity (Hartley 2002; Carnus et al. 2006; Stephens and Wagner 2007; Brockerhoff et al. 2008; Felton et al. 2010). This study focuses on deliberately planted forestry trees including pines, eucalypts, other exotic species, and trees indigenous to the plantation area; agricultural plantations 
such as coffee, tea, rubber, and cotton were not included. While we consider our review exhaustive of literature available in these databases we did not include studies not available in these databases including grey literature, unpublished studies, and studies published in non-English journals not accessible by electronic databases.

In order to evaluate the change in plant biodiversity, we included studies that compared species richness (including species richness, native species richness, and exotic species richness) data from one or more plantations with data from one or more alternative land uses. When reported we used mean species richness rather than total species richness, but recorded the former when mean species richness was not reported. Cases focusing only on a particular type of plant species richness (i.e. woody species richness) were not included.

Compiled observations in studies were divided into the following categories according to type of land use transition: (1) grassland to plantation, (2) shrubland to plantation, (3) primary forest to plantation, (4) secondary forest to plantation, and (5) degraded or exotic pasture to plantation. Grasslands and shrublands are defined as natural and semi-natural non-forested ecosystems. Primary forest consists of forest that has not been cleared, but may have been modified through activities such as selective logging, while secondary forest is naturally regenerating forest on abandoned land previously used for other purposes. European "ancient forests" (Proenca et al. 2010) or "ancient woodlands" (Brunet 2007), which are at least 200 years old, but likely were cleared at some point in the past were included in the primary forest to plantation category as they are distinct from more recent secondary forest and are considered old growth. Degraded or exotic pasture refers to areas highly degraded or with dominantly exotic species used for grazing, including one study, which examined the effects of afforestation of degraded desert grazing areas (ElKeblawy and Ksiksi 2005).

One hundred and twenty-six observations from 36 publications were included in the plant database which we believe to be an exhaustive review of published case studies available in electronic databases that match the above criteria of providing quantitative data comparing forestry plantations to alternative land uses. The database included cases from 25 countries, representing all continents (with the exception of Antarctica) with Japan (32 observations) as the most represented country (Fig. 1). Grassland and shrubland to plantation cases came from a variety of locations (including northern, southern, and eastern Europe, Africa, New Zealand, Jordan, and South America), as did primary forest to plantation cases (including Australia, South America, Africa, southern and northern Europe, and Hawai'i). The degraded or exotic pasture to plantation category included cases from the Middle East, Hawai'i, New Zealand, Australia, Central America, North America, and northern Europe. Despite the geographical breadth of these three categories, we did not find any observations from Asia. On the other hand, in the secondary forest to plantation category, the majority of observations (34 out of 54) and publications (4 out 9) came from Asia, primarily from Japan (32 cases) with an additional two cases from China. The secondary to plantation category also included cases from North America, northern and eastern Europe, and one publication from Puerto Rico, but lacked studies from Africa, South America, and other parts of Europe (Fig. 1). A total of 11 grassland to plantation, 11 shrubland to plantation, 27 primary forest to plantation, 54 secondary to plantation, and 22 exotic or degraded pasture to plantation observations were recorded. Approximately $17 \%$ were established solely for wood production, $13 \%$ for environmental protection or restoration, and $39 \%$ for mixed purposes, with the remaining $31 \%$ for an unknown purpose.

In many cases a space-for-time substitution allowed for a direct comparison between a plantation and adjacent land use that was representative of the land cover prior to plantation establishment; as much as possible, plantations were paired with land uses that 


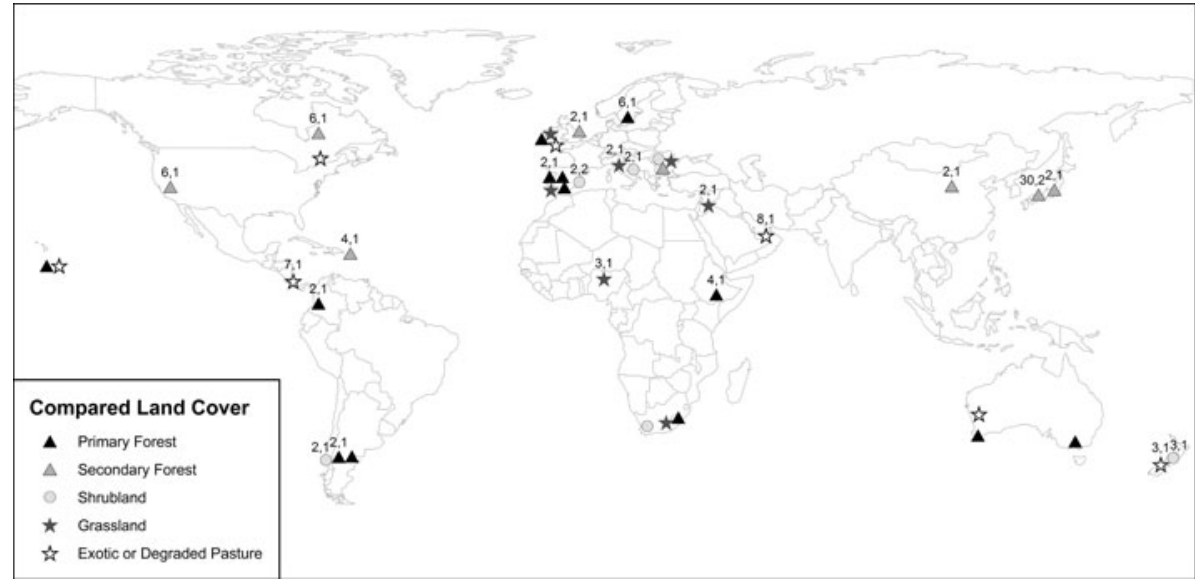

Fig. 1 Map displaying included publications and observations by category of land-use change. Points followed by $(x, y)$ refer to (publications, observations) per geographical location whereas points without $(x, y)$ refer to one publication and one observation

matched the previous land use to avoid inappropriate comparisons. In the grassland, shrubland, secondary forest, and exotic or degraded pasture to plantation categories we included only direct comparisons in that there was no intermediate land use and plantations were the cause of the land-use change. In the case of grasslands, shrublands, and almost all degraded or exotic to plantation cases, plantations were established directly on these land uses and then compared directly to adjacent or nearby remaining prior vegetation cover. In one study, however, plantations were established on a succession of grasslands and shrublands without distinguishing which plantations were established on which land cover (Cremene et al. 2005); in this case both a shrubland to plantation and grassland to plantation category were included. In another study (Ecroyd and Brockerhoff 2005), plantations were primarily established by replacing shrublands, but at the same time other shrublands were replaced by exotic pasture; in this case, both shrubland to plantation and exotic or degraded pasture to plantation cases were included.

In the primary forest to plantation category, however, the majority of cases found (19) compared primary forest to plantations established on land that was formerly primary forest but had been used for agriculture or grazing (intermediate land use) prior to planting. We included both direct and indirect comparisons in these studies in order to not lose valuable knowledge regarding the capacity of plantations to serve as restoration tools. While the intermediate land use and land use history will clearly influence biodiversity outcomes (Ito et al. 2004; Lee et al. 2005; Brunet 2007; Soo et al. 2009), these cases were included in order to not lose information and to be able to compare indirect and direct comparisons. Those transitions involving direct comparisons and those with an intermediate land use are clearly indicated in Appendix 1 (see Electronic supplementary material).

In some cases plantation biodiversity was compared with two or more alternate land uses that represented the land cover at different points over the past 50 years. For example, in Goldman et al. (2008) native plantations were established on exotic pasture that had been previously deforested. In this case, plantation biodiversity was compared to both adjacent pasture and to native primary forest with one observation classified as degraded or exotic pasture to plantation and the other as primary forestry to plantation. For studies that 
presented data from multiple plantations, each pair was recorded as a data point or observation.

All of the studies that were included reported species richness (SR, either as the mean species per unit time or area or as the total amount encountered over the entire study area) in both the plantation and paired land use; some articles included a species list in the appendix from which species richness was calculated. From these data, change in species richness following plantation establishment was calculated as follows:

$$
\text { Percent } \Delta \mathrm{SR}=(\text { Plantation SR }- \text { Control SR }) / \text { Control SR } \times 100
$$

The same was done for native species richness, narrow and endemic species richness, and exotic species richness where this information was available. Additionally, when available, the percent change in specialist, narrow or endemic species was computed by calculating the difference in percentage of narrow and endemic species between the plantation and paired land use. Specialist species were defined as such by the individual authors due to their being forest-dependant (late seral species) or open-habitat dependant in the case of grassland and shrubland transitions. Presence or absence of extremely rare or threatened/endangered species was also recorded. Site information including location, mean annual precipitation, plantation age and size, species composition, change in canopy cover, proximity to native vegetation, and silvicultural methods were also recorded where available.

\section{Statistical methods}

In order to avoid making assumptions about sample distribution and variance in categories with small sample sizes, Fisher's sign tests (signed binary-tranform tests) were used to determine whether each category of plantation transition significantly impacted measures of diversity and richness. Fisher's sign test is a conservative test with less power than Student's $t$-tests and Mann-Whitney U test, and is the preferred test in the absence of normal or symmetrical distributions. Student's $t$-tests with unequal variances were used to compare native versus exotic plantations within the secondary, primary, and exotic and degraded pasture forest transitions as data in these categories were approximately normally distributed. Non-parametric Spearman's rank correlations were used to evaluate the relationship between plantation age and species richness. All statistical analyses were done using the JMP software package (JMP 2007).

\section{Results}

\section{Effects of land-use transition type}

The type of land-use transition significantly influenced the biodiversity outcomes of plantation establishment. Plant species richness significantly decreased in grassland to plantation $(-35 \% \pm 7 \% ; \quad P<0.001)$, primary forest to plantation $(-35 \% \pm 6 \%$; $P<0.001)$, and shrubland to plantation $(-34 \% \pm 10 \% ; P<0.05)$ transitions, but significantly increased in secondary forest to plantation transitions $(35 \% \pm 8 \% ; P<0.05)$. Species richness also tended to increase in the exotic and degraded pasture $(25 \% \pm 15 \%$; $P=0.83$ ), but results were not significant due to high variability within the data (Fig. 2, Table 1). 


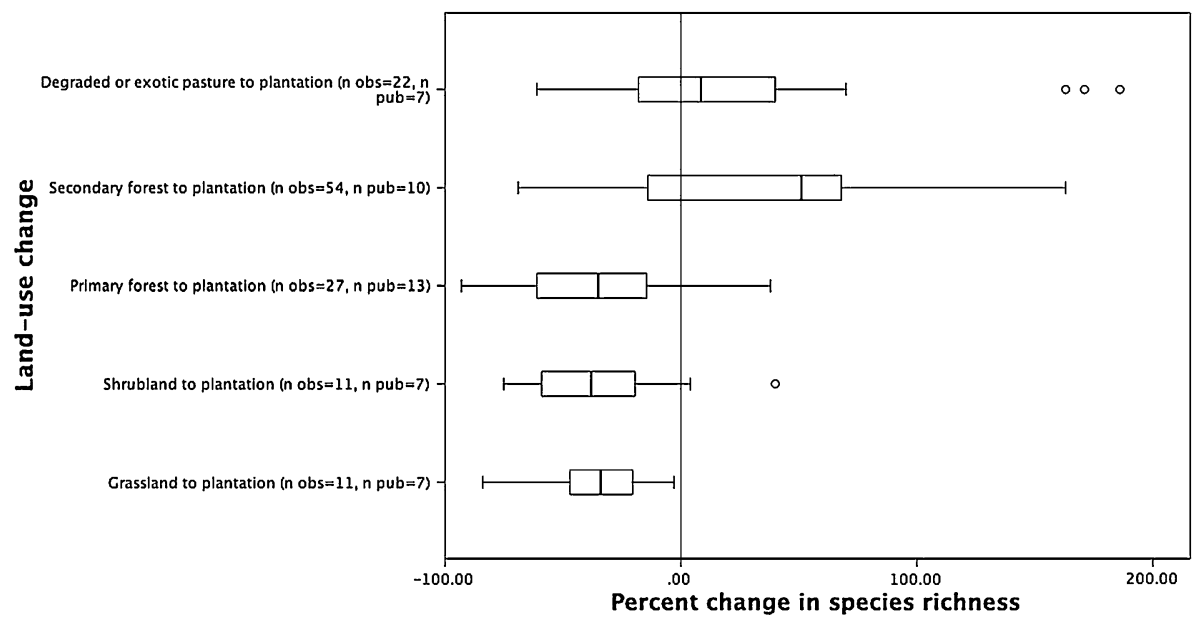

Fig. 2 Change in species richness by category of land-use change. ${ }^{*} P<0.05, * * P<0.001,{ }^{\bullet}$ Boxplot outliers

Table 1 Changes in plant species richness, specialist/endemic/narrow species richness, native species richness, and exotic species richness, by type of land-use transition

\begin{tabular}{llllllllll}
\hline Land-use transition & $\begin{array}{l}\Delta \text { Plant } \\
\text { species } \\
\text { richness (\%) }\end{array}$ & $\begin{array}{l}\text { Total } \\
n \text { (obs.) }\end{array}$ & $\begin{array}{l}\text { Total } \\
n \text { (pub.) }\end{array}$ & $\begin{array}{l}\Delta \text { Narrow } \\
\text { or endemic } \\
\text { SR }(\%)\end{array}$ & $\begin{array}{l}\Delta \text { Native } \\
\text { SR }(\%)\end{array}$ & $n$ & $\begin{array}{l}\Delta \text { Exotic } \\
\text { SR }(\%)\end{array}$ & $n$ \\
\hline $\begin{array}{l}\text { Grassland to } \\
\text { plantation }\end{array}$ & $-35( \pm 7)^{* *}$ & 11 & 7 & $-47( \pm 15)$ & 3 & $-43( \pm 16)$ & 2 & $235( \pm 235)$ & 2 \\
$\begin{array}{c}\text { Shrubland to } \\
\text { plantation }\end{array}$ & $-34( \pm 10)^{*}$ & 11 & 7 & -38 & 4 & $-55( \pm 7)^{*}$ & 4 & $36( \pm 13)$ & 5 \\
$\begin{array}{c}\text { Primary forest } \\
\text { to plantation }\end{array}$ & $-35( \pm 6)^{* *}$ & 27 & 13 & $-60( \pm 6)$ & 2 & -65 & 5 & $206( \pm 130)$ & 5 \\
$\begin{array}{c}\text { Secondary forest } \\
\text { to plantation }\end{array}$ & $35( \pm 8)^{*}$ & 54 & 10 & $12( \pm 27)$ & 6 & -17 & 1 & $53( \pm 48)$ & 2 \\
$\begin{array}{c}\text { Degraded } \\
\text { or exotic } \\
\text { pasture to } \\
\text { plantation }\end{array}$ & $25( \pm 15)$ & 22 & 7 & NA & 0 & $410( \pm 133)$ & 6 & $-39( \pm 9)^{*}$ & 6 \\
\hline
\end{tabular}

$* P<0.05, * * P<0.001$. Significance of each transition was determined using Fisher's sign tests

Afforestation: grassland to plantation and shrubland to plantation

Afforestation of natural grasslands and shrublands resulted in a decrease in species richness and diversity in all but two cases. The two cases where species richness increased were both in the shrubland to plantation category and were from a publication on the effects of afforestation of a highly endemic but naturally species poor ultramafic grassland in Italy (Chiarucci and Dedominicis 1995). While overall species richness increased with plantation establishment, specialist and endemic species richness decreased; as such, the increase in total species richness can be attributed to the expansion of generalist or exotic species (Chiarucci and Dedominicis 1995). Although few afforestation publications reported this 
measure, those that did reported a decline in richness of narrow/endemic/specialist species (species noted by author as restricted to a particular habitat type), with an average decrease of $47 \%( \pm 15 \%)$ in the three grassland cases where it was reported and $38 \%( \pm 11 ; n=4$; $P<0.05$ ) in shrubland afforestation (Table 1). Exotic species richness was unaffected in one grassland to plantation case (Cremene et al. 2005) while in the other case reported it increased by $470 \%$ (O'Connor 2005). Exotic species richness increased in all five shrubland to plantation cases (mean $=36 \%)$, but not significantly so $(P=0.41$; Fig. 3$)$. Native species richness, in contrast, decreased in all afforestation cases and significantly so in the shrubland to plantation category (55\% decrease, $n=4, P<0.05$; Table 1 ).

Primary forest and secondary forest to plantation

Species richness was lower in plantations than in primary forest in 24 of 27 cases with a mean decrease of $35 \%$ across all observations (Table 1; Fig. 2; $P<0.001$ ). Eight of the 27 cases were direct comparisons, meaning that plantations replaced natural forests, while 19 of the cases involved an intermediate land use whereby plantations were established on previously deforested land that had been used for another purpose, most often grazing (Appendix 1 includes details on the intermediate land use for each case). Overall, plantations replacing primary forests were $39 \%( \pm 8 \%)$ less species rich than paired primary forest $(P<0.05)$, while those with an intermediate land use were $33 \%( \pm 8 \%)$ less species rich than paired primary forests $(P<0.01)$. Likewise, native species richness significantly decreased by $65 \%( \pm 10 \%)(P<0.05)$ in the five cases reported in the primary forest. Results of exotic species richness were variable in the five primary forest to plantation transitions where it was reported, ranging from a $510 \%$ increase to a $23 \%$ decrease $(P=0.65)$ and was higher in plantations in three out of the five cases reported (Fig. 3). In one case exotic species richness was unaffected by plantation establishment; in the one case where exotic species richness was higher in the primary forest than plantation, the abundance of exotic species was lower in the primary forest (Goldman et al. 2008).

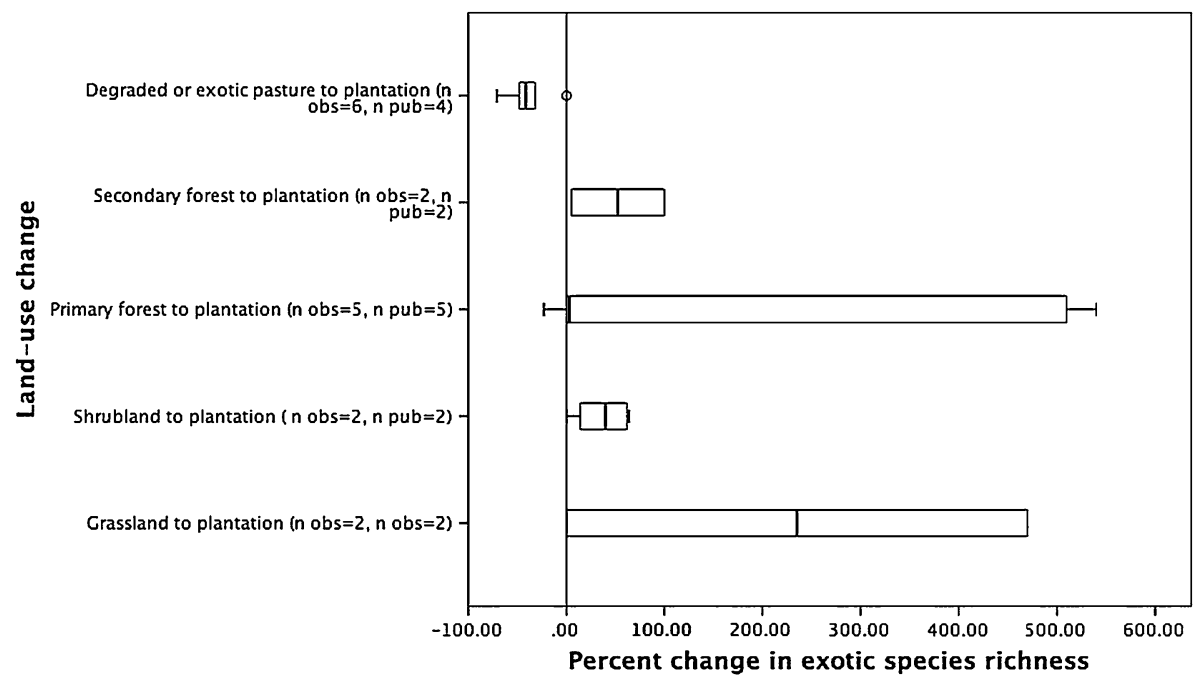

Fig. 3 Change in exotic species richness with plantation establishment by category of land use change. $* P<0.05$. ${ }^{*}$ Boxplot outliers 
Moreover, in this case, native species richness and overall species richness decreased with plantation establishment, indicating a much more abundant and diverse native understory in primary forests compared to plantations.

In contrast, species richness significantly increased in the secondary forest to plantation category $(P<0.05$; Table 1 ; Fig. 2$)$, despite considerable heterogeneity among results, with plantations being less species rich than secondary forests in 18 of the 54 cases. Nonnative species richness was reported in two cases in the secondary forest to plantation category (Fig. 3). One was a group of plantations that used native species where exotic species richness increased by approximately $5 \%$ (data estimated from figure) (Battles et al. 2001). The other was an exotic species plantation, which reported one non-native species in the plantation compared to none in the paired secondary forest (a 100\% increase) while native species richness declined $17 \%$ (the one case reporting native species richness in the secondary forest to plantation category) with plantation establishment (Cremene et al. 2005). Narrow/endemic/specialist species richness increased $12 \%( \pm 27 \%)$ overall, but was highly variable and swayed by one case where narrow/endemic/specialist species richness increased by $144 \%$ (Cremene et al. 2005), whereas, four out of six cases resulted in a decrease in narrow/endemic/specialist species.

\section{Exotic or degraded pasture to plantation}

Species richness in plantations established on exotic or degraded pasture increased in 13 of 22 cases, but the mean increase of $25 \%( \pm 15 \%)$ was not significant $(P=0.83)$ (Fig. 2; Table 1). Exotic species richness significantly decreased by $39 \%(P<0.05 ; n=6)$, while native species richness increased by $410 \%(P=0.11$; Fig. 3$)$. Species richness in plantations utilizing native species increased an average of $45 \%(n=14)$ while in plantations utilizing non-native species, species richness decreased overall by $12 \%(n=8)$, although neither of these was significant. It should be noted that several publications finding large increases in woody species richness in both exotic and native plantations established on degraded or exotic pastures (Parrotta 1995; Cusack and Montagnini 2004) were excluded because they did not include herbaceous species richness, but do indicate the high capacity of plantations to restore woody diversity, which is sometimes the goal of plantation establishment (both native and exotic) on degraded lands.

\section{Effects of plantation species}

We found a highly significant $(P<0.001)$ difference between plantations utilizing native species $(n=43)$ versus those using exotic species $(n=11)$ in the secondary forest to plantation category. While native species plantations were $51 \%( \pm 8 \%)$ more species rich than paired secondary forests, exotic species plantations were $29 \%( \pm 6 \%)$ less species rich than paired secondary forests (Fig. 4). It should be noted here, however, that 29 of the 43 native species plantation cases were from a single study (Nagaike et al. 2006) with a total of four studies providing data for native plantations compared with naturally regenerating forests, indicating the need for more studies from more diverse regions (Fig. 1). We found a similar trend in primary forest to plantation transitions where plantations using exotic species tended to experience somewhat greater declines in species richness $(-42 \% \pm 9 \%)$ than those using native species $(-30 \% \pm 9 \%)$, but this difference was not significant $(P=0.353$; Fig. 5$)$. Native species plantations $(n=14)$ established on exotic or degraded pastures were also significantly $(P<0.05)$ more effective in 


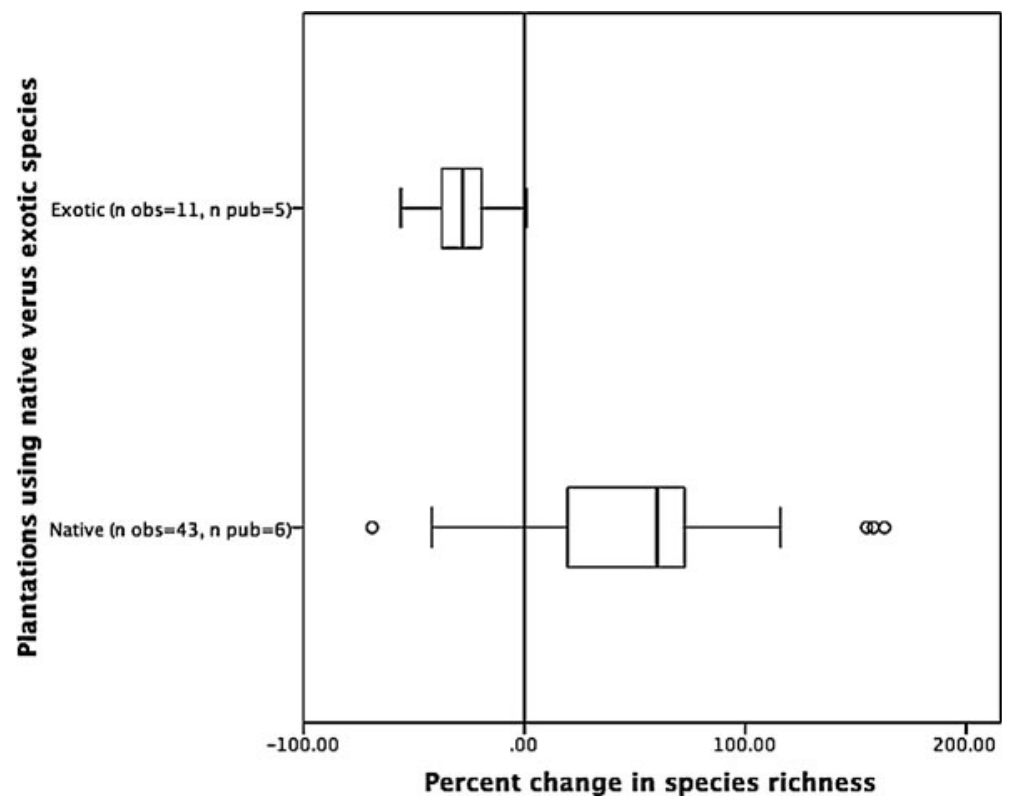

Fig. 4 Change in plant species richness with plantations using native versus those using exotic species in secondary forest to plantation transitions $(P<0.001){ }^{\bullet}$ Boxplot outliers

restoring species richness $(45 \% \pm 20 \%$ increase) compared to exotic species plantations $(n=8 ;-12 \% \pm 14 \%)$, however, the number of observations was small with substantial variation among them.

We found no significant differences between plantations using single or mixed species; there were, however, few cases using mixed species, making this relationship difficult to assess. All plantations in shrubland were conifers (and thus, evergreen), making a comparison of plantations with conifers versus broadleaf impossible in this category. Seven of ten plantations used conifers in grassland to plantation transitions, which resulted in a decrease in species richness of $40 \%( \pm 8 \%)$ versus $19 \%( \pm 10 \%)$ in broadleaf plantations, but sample sizes were too small to run statistical comparisons in this category. There was no significant difference in the primary forest to plantation category with conifers $(n=14)$ and broadleaf trees $(n=13)$ decreasing species richness by $33 \%( \pm 9 \%)$ and $36 \%( \pm 8 \%)$, respectively. In the secondary forest to plantation category, conifer plantations $(n=48)$ were significantly more species rich $(43 \% \pm 8 \%, P<0.001)$ than paired secondary forests while broadleaf plantations $(n=6)$ supported significantly fewer species $30 \%( \pm 5)$ than paired secondary forests $(P<0.05)$. Due to small sample size of the broadleaf plantations, conifer and broadleaf plantations were not statistically compared directly to each other. These results are also confounded by the fact that 40 of the conifers are native species (three of the broadleaf plantations were native and three exotic) and thus established in areas with natural conifer forests, which would affect biodiversity outcomes differently than in areas with native broadleaf forests forested with conifer species. In the exotic or degraded pasture to plantation category species richness decreased overall by $2 \%( \pm 16 \%)$ with conifer plantations $(n=6)$ and increased $34 \%( \pm 19 \%)$ in broadleaf plantations $(n=16)$, but neither of these tendencies was significant. 


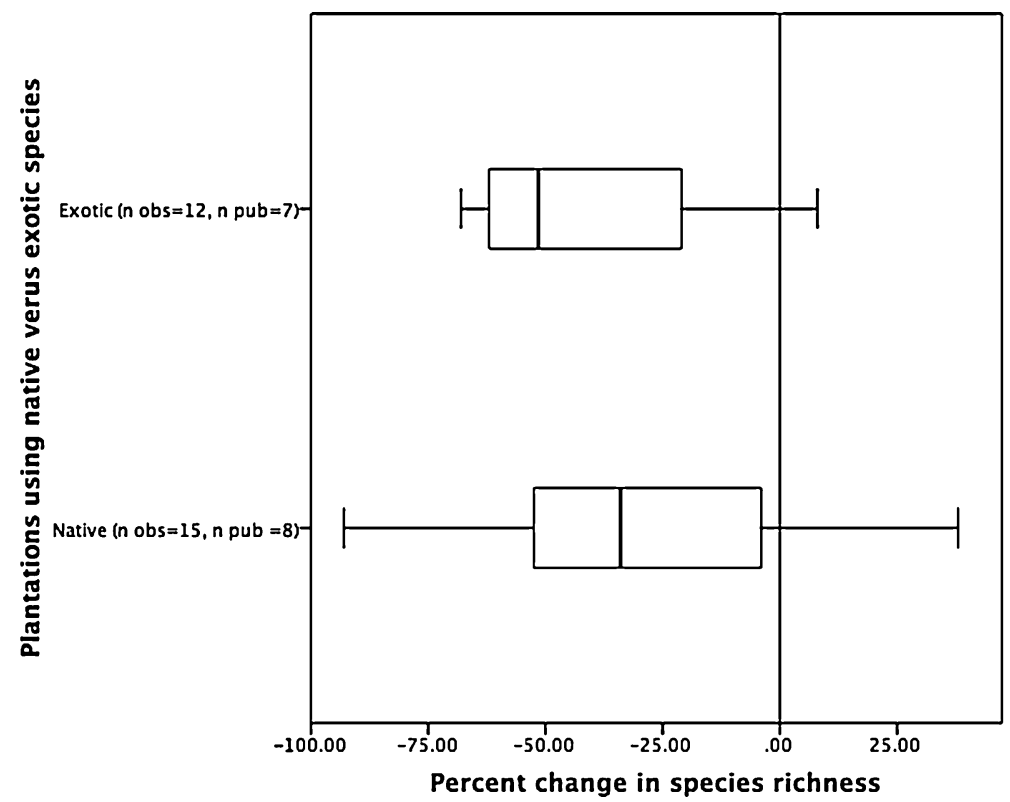

Fig. 5 Change in plant species richness with plantations using native versus those using exotic species in primary forest to plantation transitions. ${ }^{\bullet}$ Boxplot outliers

Effects of plantation age

Species richness significantly decreased with plantation age with grassland afforestation ( $R^{2}=0.673, P<0.05$, Spearman's correlation) and tended to decrease with shrubland plantation $\left(R^{2}=0.475\right.$, Spearman's correlation) although not significantly so $(P=0.140)$. No relationship with plantation age was found in the primary forest, secondary forest, or exotic or degraded pasture to plantation categories, nor were differences found when dividing plantations into age categories (young: $\leq 7$ years; mid-aged: 8-24 years; mature: $\geq 25$ years).

\section{Management and location effects}

Unfortunately, beyond the species used, there was inadequate information available regarding management regime, including site preparation, tree spacing, and whether or not plantations were thinned. We used canopy cover as a proxy for management since increased canopy openness through thinning, spacing, or species selection is thought to influence biodiversity outcomes (Michelsen et al. 1996; Hartley 2002). Canopy cover was obviously greater in plantations than in grasslands, shrublands, and exotic or degraded pasture areas. We found no significant difference in canopy cover in primary and secondary forests versus plantations, but this may be due to a small sample size. Of the cases reporting canopy cover in the primary and secondary forest categories, a higher proportion of exotic plantations had higher canopy cover than did native plantations. All native plantations reporting canopy cover had a lower canopy cover than paired secondary forests.

The proximity of plantations to native vegetation or seed sources can also have an effect on biodiversity outcomes (Hartley 2002; Carnus et al. 2006; Brockerhoff et al. 2008; 
Felton et al. 2010). While few studies reported in detail distance to native vegetation, we classified plantations as "near or adjacent to native vegetation," when the authors indicated the existence of native vegetation in close proximity, or "isolated," where authors pointed out that plantations were separated, by a geographical or land-use barrier, from natural vegetation. The vast majority of studies reported the existence of nearby native vegetation, including all but one afforestation case (where the entire watershed was afforested), all of the secondary forest to plantation transitions, 21 out of 27 primary forest to plantation transitions, and 13 out of the 22 degraded or exotic forest to plantation transitions (with the other nine cases not reporting this measure). In the primary forest to plantation category the three cases where plantations were isolated from native vegetation tended to be less species rich than paired primary forests $(53 \% \pm 7 \%$ less species rich) compared to those near native forest $(-28 \% \pm 6 \%$ less species richness), but the small sample size makes it difficult to draw any conclusions. As few studies reported distance to native vegetation in detail, further information is necessary to evaluate these relationships.

\section{Discussion}

The value of increasing forest cover depends in large part on the characteristics, or ecological quality, of the resulting forests (Farley 2007; Perz 2007; Lambin and Meyfroidt 2010; Putz and Redford 2010). The results of this synthesis clearly indicate that a number of factors, including previous land use, plantation species, and, in some cases, plantation age, influence whether biodiversity increases or becomes more impoverished following plantation establishment. Here, we have identified several characteristics of plantations that can have a strong influence on biodiversity outcomes.

Negative impacts on biodiversity: grassland, shrubland, and primary forest conversions

This synthesis suggests that conversion of natural and semi-natural grasslands and shrublands or of primary forest is likely to be detrimental for biodiversity (Fig. 2). Our results concur with other studies that show afforestation of natural ecosystems alters habitat substantially for native flora and fauna (Richardson and Van Wilgen 1986; Van Wesenbeeck et al. 2003; Alrababah et al. 2007; Lantschner et al. 2008), with particularly strong negative effects on specialist grassland and shrubland species (Andres and Ojeda 2002; Freemark et al. 2002; Buscardo et al. 2008). While Felton et al. (2010) found no significant differences in plant species richness between plantations and pasture lands, their study grouped together native and artificial grasslands used for grazing into one pasture category. Thus, it is possible that some of the "unexplained heterogeneity" (Felton et al. 2010 , p. 6) they found may be due to the broad range of land covers included in their pasture lands category, highlighting the importance of previous land cover and use.

The loss of plant diversity and richness with afforestation of natural and semi-natural grasslands and shrublands has been attributed to a number of factors including site preparation, exclusion of shade intolerant native species by plantation canopy cover, allelopathy, and the physical barrier of litter (particularly pine litter) to germination (Maccherini and De Dominicis 2003; O'Connor 2005; Alrababah et al. 2007; Buscardo et al. 2008). Changes in land management with plantation establishment, such as the exclusion or alteration of grazing regimes or draining, can affect plant diversity and community structure as well (Buscardo et al. 2008). Plantation establishment will also differentially affect particular native grassland and shrubland species (Igboanugo et al. 1990; Van 
Wesenbeeck et al. 2003; Cremene et al. 2005; Chirino et al. 2006) as in the case of native fynbos afforestation in South Africa where geophytes and wind dispersed species survived under plantations whereas woody large-leaved species such as protea did not (Richardson and Van Wilgen 1986). Changes in community structure are also reflected in changing amounts of exotic versus native species. While native species richness decreased in all cases that reported it, exotic species increased (or was unaffected in two cases) in all reporting cases. Increased dominance of exotic species may be attributed to increased disturbance, changes in light and soil conditions, and, in some cases, changes in land management, including exclusion of grazing (Buscardo et al. 2008).

Natural grasslands and shrublands have historically received little conservation attention in comparison to forested ecosystems (Andres and Ojeda 2002; Putz and Redford 2010). The low number of case studies in the shrubland to plantation and grassland to plantation categories is reflective of the paucity of publications examining the effects of afforestation on biodiversity. While this is changing with increased appreciation of their high biodiversity value, many non-forested ecosystems lack formal conservation measures to prevent afforestation (Andres and Ojeda 2002; Buscardo et al. 2008) and are rarely given consideration in carbon-based conservation efforts (Putz and Redford 2010). Afforestation of natural and semi-natural grasslands and shrublands has been shown to decrease soil carbon and stream flow (Guo and Gifford 2002; Farley et al. 2004, 2005) and to increase stream acidity (Farley et al. 2008). Given that other ecosystem services, in addition to biodiversity, are also often adversely affected, afforestation of natural and semi-natural grasslands and shrublands, from an ecological perspective, can be seen as generally leading to a suite of negative impacts (Brockerhoff et al. 2008; Buscardo et al. 2008).

Our finding that primary forests supported an average of $35 \%$ more species than plantations is not surprising as, regardless of management, species selection, age, or landuse history, primary forests will most often support higher levels of native species richness and abundance than plantation forests (Cavelier and Tobler 1998; Lindenmayer and Hobbs 2004; Brockerhoff et al. 2008; Goldman et al. 2008). The intensity of land use during any intermediate agricultural phase can affect soil properties, the amount of relict vegetation, and micro-topography, which in turn will influence biodiversity outcomes (Aubin et al. 2008; Brockerhoff et al. 2008). For this reason, it is important to distinguish between plantations directly replacing native forests and plantations established in already degraded areas in order to avoid "inappropriate comparisons" (Paquette and Messier 2010). In doing so, we found a slightly greater decrease in species richness with direct comparisons (39\% less species rich; plantations replacing primary forest) than those with an intermediate land use (33\% less species rich). While the number of direct comparisons was small $(n=8)$, the fact that we found a significant decrease in species richness in primary forest to plantation transitions, whether or not an intermediate land use existed, suggests that plantations do not function to restore biodiversity to levels approaching that of primary forests on sites previously covered with primary forest regardless of the intermediate use, but the plantations could be considered to restore biodiversity compared to the intermediate land use.

Lower levels of species richness in plantations compared to primary forests is likely due, in part, to the high level of structural complexity in natural forests that is required for seed germination in some plant species, particularly late seral and animal dispersed species (Lindenmayer and Hobbs 2004; Carnus et al. 2006; Paritsis and Aizen 2008). Lower diversity in plantations may also be due to the paucity of seed sources (Gonzales and Nakashizuka 2010) and by changes in decomposition rates and litter fall with plantation establishment (Barlow et al. 2007b). In general, plantations contain a subset of primary 
forest species (FAO 2006), with lower levels of diversity and richness (Pomeroy and Dranzoa 1997; Fahy and Gormally 1998; Yirdaw 2001), but may be dependant upon adjacent or nearby forests for regeneration (Paritsis and Aizen 2008; Onaindia and Mitxelena 2009). As indicated by our results and discussed below, plantations (particularly young plantations) also tend to favor establishment of ruderal or exotic species over large, gravity dispersed or late seral species, leading to a change in species composition often not reflected in changes in overall species richness (Ito et al. 2004; Paritsis and Aizen 2008).

Given that approximately half of plantations are established through conversion of natural forests, it is clear why many environmental groups rally against plantation forestry (Hartley 2002; Brockerhoff et al. 2008). While plantations represent a proximate driver for a small percentage of deforestation (7\%), they still constitute an important threat to native flora and fauna (FAO 2001). Although plantations may represent a "lesser evil" relative to other more intensive land uses, it is clear from a biodiversity perspective that primary forests (and other non-forested natural lands) should not be converted to plantations (Brockerhoff et al. 2008).

Variable impacts on biodiversity: secondary forest and degraded and exotic pasture to plantation conversions

Although species richness significantly increased in the secondary forest to plantation category, the diversity of results among case studies reflects the varied outcomes in studies quantifying biodiversity in plantations compared to secondary forests (Hartley 2002). This suggests that secondary forest to plantation conversions need to be evaluated on a case-bycase basis, and the value of this land-use change depends to a large degree on the objectives of the plantation. While plantation forests can result in rapid development of a forest structure beneficial for some wildlife species (Duran and Kattan 2005), it is widely believed plantations generally have less developed understories due to the intensity of site preparation (Marcos et al. 2007), frequent uniformity of plantation forest structure (Barlow et al. 2007a; Aubin et al. 2008), and changes in ecological processes of decomposition and litterfall (Barlow et al. 2007b). In some locations, secondary forests “....are essentially forest fallows subject to reclearing" (Putz and Redford 2010, p. 16), while in many parts of Europe, where few primary forests remain, the distinction between secondary forest and very old plantations may be blurred and plantations are seen as playing an important role in biodiversity conservation (Humphrey 2005, Brockerhoff et al. 2008). In these cases, the type of plantation species can play an important role, as "plantation forests can be expected to be better equivalents of natural forests if they are composed of locally occurring native tree species, and in some cases it may be difficult to distinguish older stands from natural forest" (Brockerhoff et al. 2008, p. 935).

Our results suggest that the species used in plantation play a particularly important role in secondary forest to plantation conversions (Fig. 4). While exotic plantations support lower levels of plant diversity, native plantations may actually support more diversity than comparable secondary forests. This is a particularly interesting comparison given the increasing trend of both natural forest regeneration and plantation establishment; in tropical regions, the area of natural forest converted to plantations each year approximately equals the area of naturally regenerating forests, while secondary forest growth exceeds the conversion rate of natural forest to plantations by three times in temperate regions (FAO 2006). It should be noted, however, that 29 of the 42 native secondary plantations in our synthesis were from one publication in Japan comparing 2-77 year-old Larix kaempferi plantations with secondary forests (Nagaike et al. 2006). The authors found significantly 
higher species richness and diversity in plantations, which they attribute to differences in management. The authors suggest thinning and weeding of plantations created disturbances that increased vine, annual, and fern growth forms and gravity-dispersed species, but that decreased the number and richness of tall tree species and bird dispersed species in plantations compared to naturally regenerating forests (Nagaike et al. 2006). While they did not find any significant relationship between understory diversity and richness of plantations and plantation age, they did find differences in community structure, with older plantations being more similar to naturally regenerating forests and younger plantations having higher proportions of weedy species (Nagaike et al. 2006). The results of this synthesis do not suggest that replacing secondary forests is beneficial for biodiversity, but that in some cases plantations (particularly those using native species) can provide more or comparable benefits to similar aged naturally regenerating forests.

Across a range of taxa, plantations often support intermediate levels of biodiversity, which are lower than natural ecosystems but higher than other "working" or humanmodified landscapes (Senbeta et al. 2002; Brockerhoff et al. 2008; Goldman et al. 2008). The exotic or degraded pasture category of land use in this synthesis represents deforested, primarily exotic and degraded pastures that likely had economic value at some point, primarily through grazing; in these cases, plantations (of some species) may offer an alternative viable "working landscape" that also has economic value (Brockerhoff et al. 2008; Goldman et al. 2008). In addition to potential economic revenue, plantations have been shown to aid restoration in degraded areas where native regeneration may otherwise be inhibited, by improving soil conditions through increased organic matter and litter production (Senbeta et al. 2002), by shading out competitive grasses and other lightdemanding species (Parrotta 1995; Koonkhunthod et al. 2007), and by creating a microclimate more favorable for seed dispersal and colonization, particularly for animal-dispersed species (Parrotta 1995; Hartley 2002; Carnus et al. 2006; Goldman et al. 2008). How effective plantations are in restoring biodiversity is expected to be influenced by past land use, distance to native seed source, persistence of root stocks and seed bank, and presence of seed dispersing wildlife, as well as plantation species, age, and management (Yirdaw 2001; Cusack and Montagnini 2004; Goldman et al. 2008).

Our results regarding the restoration value of plantations on pasture lands were variable and differences were not significant, but the trend towards higher species richness with native plantations and lower species richness with exotic plantations suggests that native plantations may be a better choice for restoration of degraded or exotic grasslands. Species richness was higher in 10 out of 14 native plantations compared to paired pastures. Furthermore, one of the cases where species richness was higher in pastures compared to native plantations was attributed to a greater number of exotic species (rather than native species) in pastures (Goldman et al. 2008). The other three cases came from a study noting that "there were probably substantial edge effects from the surrounding plantations upon the relatively small control areas" (Powers et al. 1997, p. 45), suggesting that species richness of paired pastures may have been overestimated.

Through wood and non-timber production or through carbon sequestration programs and other payment for ecosystem programs, plantations replacing "working lands" with low biodiversity may continue to provide economic revenue (Goldman et al. 2008). While the results of this synthesis were highly variable for these landscapes, a number of cases with increased species richness in plantations compared to paired pastures indicate that plantations (with some species) established on degraded/cleared lands may sometimes present a win-win situation where both environmental and economic goals are met (Lugo 1997; Lamb 1998). As noted by Carnus et al. (2006, p. 68), "In many circumstances 
plantations may be the only economic means by which to overcome large scale degradation. In these circumstances the issue is not whether to establish plantations but, rather, what kind of plantation to establish." Where native species are used, plantations may better create canopy cover and soil chemistry conditions that favors native over exotic species colonization (Skowcroft and Jeffrey 1999 in Goldman et al. 2008).

\section{Influence of plantation species}

One of the most interesting findings in this synthesis is that while exotic plantations were, overall, less species rich than natural and semi-natural ecosystems (shrublands, grasslands, primary, and secondary forests), on average, native plantations were significantly more species rich than secondary forests. This may be due to a number of management and structural factors that transcend the categorization of "native" versus "exotic." Stephens and Wagner (2007), for example, conclude that native plantations are generally more similar in habitat structure to natural forests than are exotic plantations and therefore support a more diverse flora and fauna. As stated by Brockerhoff et al. (2008, p. 935): "Plantation forests can be expected to be better equivalents of natural forests if they are composed of locally occurring native tree species." This statement does not assume that exotic plantations are always "green deserts" since, "even exotics can have understory resembling native forests" (Brockerhoff et al. 2008).

Whether plantations with native species increase plant biodiversity or not, they may also have extra value for faunal diversity due to masting cycles and fruit and nectar quality (Hartley 2002). Other studies have found native plantations important for endangered faunal species providing an important restoration tool that balances environmental and economic goals (Pejchar et al. 2005). Hartley (2002) advocates for the use of native species due to the vast number of largely undiscovered invertebrates and microorganisms that may only survive in native plant species. However, considerable biodiversity, including endangered faunal species, has also been found in some exotic plantations, suggesting that they can also provide important habitat (Brockerhoff et al. 2003, 2005, 2008; Quine and Humphrey 2010). Native plantations are also viewed as preferable from a landscape perspective as they preclude the risk of exotic trees associated with exotic plantations (Lamb 1998; Estades and Temple 1999; Richardson et al. 2008), although the potential for genetic contamination of local species with exotic genotypes must also be considered (Carnus et al. 2006; Aubin et al. 2008). Native species should also be locally native, rather than simply regionally native, as in the case of the plantation tree, Queensland maple, which is native to Northern Queensland but threatens native forests in Subtropical Australia (Kanowski et al. 2003).

Furthermore, because many plantations established for wood production use exotic species (FAO 2001), the longer-term effects on biodiversity are also likely to be influenced by the plantation species, and the interaction between the plantation species and the purpose of plantation establishment. However, it should be noted that native species are increasingly recognized as valuable timber species (Hartley 2002; Goldman et al. 2008) and a number of countries including China and the United States generally use native species in plantations (Brockerhoff et al. 2008). Ultimately, these issues that influence the "wider context" of plantations will have important implications for their long-term sustainability (Brockerhoff et al. 2008, p. 928).

In addition to the species themselves, a number of authors have suggested that deciduous and/or broadleaf plantations are preferable for biodiversity conservation to conifer and/or evergreen plantations (Lemenih and Teketay 2005; Aubin et al. 2008). Reasons include greater similarity between deciduous plantations and natural forests in places 
where native forests are deciduous (Aubin et al. 2008) and limits on understory regeneration resulting from an acidic and nutrient limited needle layer and low light conditions in conifer plantations (Michelsen et al. 1996; Senbeta et al. 2002; Aubin et al. 2008). It has also been suggested that broadleaf plantations are more structurally complex than conifer plantations, leading to an increase in seed-dispersing wildlife and microclimate heterogeneity required for regeneration (Cheng and Lai 2002; Carnus et al. 2006). Others, however, have suggested that factors such as tree spacing and density, land use history, and plantation age can often be more important than plantation species (Geldenhuys 1997; Proenca et al. 2010).

In this synthesis we found deciduous and broadleaf plantations significantly less species rich overall than conifer or evergreen species for secondary forest to plantation transitions. This may be due to the fact that the vast majority of secondary forest to plantation transitions (44 of 54 overall and 40 of 43 native plantations) examined conifer plantations established in areas with native conifer forests. As plantation diversity may be enhanced "by creating understory environmental conditions comparable to natural forests" (Aubin et al. 2008, p. 2473), conifer plantations established in areas with native conifer forests would likely not have the degree of negative effects seen where conifer plantations are established in areas with natural deciduous or broadleaf forests (Paritsis and Aizen 2008). However, while not significant and the sample size is too small to draw conclusions, conifers did cause a greater decrease in species richness than broadleaf plantations in grassland to plantations transitions which may be due to these broad differences in forest structure. Due to the small sample size, our results also were variable and inconclusive regarding the general belief that mixed species plantations support more native species abundance and diversity than monocultures (Hartley 2002; Stephens and Wagner 2007).

\section{Plantation age}

Older plantations established on previously forested lands, are generally expected to support higher levels of diversity given additional time to develop structural complexity (Lugo 1992; Munro et al. 2009), and favorable microclimates and litter and humus layers that are more conducive to native plant colonization (Geldenhuys 1997; Brockerhoff et al. 2003, 2008; Nagaike et al. 2006). Other studies, however, have found high levels of species richness in younger plantations, but have primarily attributed this to an increase in light-demanding ruderal and often exotic species, with native forest species increasing with plantation age (Ito et al. 2004; Nagaike et al. 2006; Soo et al. 2009). On the other hand, plantations established on natural or semi-natural shrublands and grasslands would be expected to have a greater negative effect on native species with age, increasing canopy cover, and with multiple rotations (Wallace and Good 1995; Maccherini and De Dominicis 2003; O'Connor 2005). Our results provide some support for this idea, with a significant negative relationship with plantation age and species richness in the shrubland to plantation category and an insignificant but similar trend with grassland afforestation. Clearly, this would also depend on the particular growth rate of the plantation species used, the ecological characteristics of native understory species, and other environmental and site conditions including adequate seed sources and climate conditions (Hartley 2002; Cusack and Montagnini 2004).

\section{Management effects}

Discussions of management strategies to conserve biodiversity in plantations are generally focused on enhancing habitat for forest species. In a synthesis of management 
recommendations to improve biodiversity outcomes of plantations established on previously forested lands, Hartley (2002) suggests (1) leaving remnant native trees, snags, and cavity trees during harvest, (2) managing plantations on longer rotations, (3) utilizing native species over exotics and polycultures over monocultures, (4) avoiding intensive site preparation, and (5) thinning some plantations heavily and others not to maintain a mosaic of open to non-open areas to encourage native species colonization. Of these recommendations we found clear support for using native species over exotic species. While we did not have sufficient information on the amount of remnant native vegetation left in plantations, this, in addition to proximity to native forest, is likely a key control on biodiversity outcomes (Goldman et al. 2008). In some cases, regeneration of native species in plantations may depend on colonization from adjacent or nearby native ecosystems (Senbeta et al. 2002; Paritsis and Aizen 2008). Relatively few publications reported sufficient detail on distance, making this factor difficult to analyze.

Canopy openness is also regarded as an important factor influencing understory richness where plantations with wider spacing (either due to plantation species or management practices), and thus more open canopies, allow more light to reach the understory (Michelsen et al. 1996; Cannell 1999; Brockerhoff et al. 2003; Lemenih and Teketay 2005; Carnus et al. 2006). While thinning generally facilitates the establishment of shrubs and herbaceous flora, it also can favor primarily generalist and exotic species which thrive with increased light and moderate which than compete with native species, such as forest herbs and native late seral woody species (Herault et al. 2004; Newmaster et al. 2006; Aubin et al. 2008). Moderate levels of disturbance are generally seen as beneficial for biodiversity, but severe disturbance creates conditions few plants can tolerate (Battles et al. 2001) and even moderate disturbance can create conditions that facilitate colonization of disturbance-adapted, ruderal species, particularly in areas with problems with invasive species (Brockerhoff et al. 2003). Unfortunately, there was not adequate information on spacing, thinning, and canopy cover provided in the studies included in the database to conduct a detailed analysis on the effects of canopy openness on plant diversity. We found no significant relationship between whether canopy cover was greater or lesser in plantations versus the paired land-use, although small sample size made this difficult to analyze. The fact that all native plantations in the secondary to plantation category had a lower canopy cover than the paired land use may be indicative of increased management (particularly thinning) in plantations compared to naturally regenerating forest and may result in increasing species richness of some species (Nagaike et al. 2006). While we did not find significant relationships between measures of biodiversity and management, plantation age, and other factors, greater availability of data on these topics could help to clarify the role they play.

\section{Influence of biodiversity measure used}

While species richness is an often-used proxy for biodiversity it does not take into account which species are increasing or decreasing and thus does not reflect changes in species composition (Nagaike et al. 2006; Duan et al. 2009). While in some cases plantations support more species than paired land covers, it is important to take into account which species benefit from plantation establishment and which are negatively affected by it, which depends largely on the functional characteristics of particular species, such as seed size, dispersal agent, shade tolerance, and maximum plant height (Nagaike 2002; GomezAparicio et al. 2009; Gonzales and Nakashizuka 2010). 
It is also important to consider changes in specialist or narrow and native (especially endemic) species richness, as these species are often the most sensitive to land-use change (Ogden et al. 1997; Brockerhoff et al. 2003). Few studies reported specialist/narrow/ endemic species richness; those that did all reported a decrease in grassland, shrubland, and primary forest to plantation transitions, whereas results were mixed in the secondary and degraded or exotic pasture to plantation categories. The relatively short rotation of plantations can be particularly discriminating against old forest succession species, decreasing the value of plantations as compared to natural forests (Richardson and Van Wilgen 1986; Alrababah et al. 2007; Buscardo et al. 2008), and afforestation of natural grasslands and shrublands has been found to have particularly detrimental effects on narrow specialist species (Michelsen et al. 1996; Battles et al. 2001; Ito et al. 2004; Nagaike et al. 2006).

It is also critical to consider how plantations affect the number and abundance of exotic species since non-native species, when invasive, can compete with indigenous species and change ecosystem functioning (Richardson et al. 2000). While the limited number of studies precludes drawing strong conclusions, the results of this synthesis support past research that suggests that plantations tend to lead to an increase in exotic species (Fig. 3) and a decrease in native species richness compared to natural ecosystems (grasslands, shrublands, primary forests, and secondary forests) (Parrotta 1995; Cusack and Montagnini 2004; Brockerhoff et al. 2008) (Table 1). On the other hand, we found a decrease in exotic species and an increase in native species in degraded or exotic pasture to plantation transitions, suggesting that plantations can be effective in shading out competitive exotic species under those conditions (Carnus et al. 2006; Brockerhoff et al. 2008; Buscardo et al. 2008).

\section{Conclusion}

At local, national, and international levels, there is increasing emphasis on evaluating the impact of plantations on biodiversity and in enhancing biodiversity outcomes through landuse planning and forest management (Kanowski et al. 2003; Richardson and van Wilgen 2004). In evaluating plantations as a sustainable land use, it is important to consider how this type of land-use change will affect a range of environmental goods and services including forestry products, water supply, carbon cycling, and biodiversity. The primary recommendation from this study is that plantations are more likely to positively benefit biodiversity (particularly in terms of favoring native over exotic species) when established on degraded or exotic land covers rather than as a replacement of natural ecosystems, whether those systems were originally forested or not. At the same time, this study makes clear that further research is needed on the biodiversity outcomes of shrubland and grassland afforestation as few studies were available in these categories. In addition, the trends we found suggest that new plantations should utilize indigenous tree species to enhance within-plantation biodiversity, but more research is needed on the effects of afforestation in grasslands and shrublands using species that are native to nearby forests or woodlands versus exotic species (Carnus et al. 2006; Brockerhoff et al. 2008). However, exotic plantations do support some biodiversity, even when compared to primary forest, and should not necessarily be considered 'green deserts' or completely dismissed by conservation biologists. Thus, although plantations often support fewer specialist species than natural ecosystems, under some conditions they can play an important role in biodiversity conservation and recuperation, particularly at the landscape level. 
Acknowledgments We thank the Geography Department at San Diego State University for support of this project and we are grateful for the comments of two anonymous reviewers that helped us improve on an earlier version of this manuscript. We also thank Will Anderson for creating the map of publications and observations.

Open Access This article is distributed under the terms of the Creative Commons Attribution Noncommercial License which permits any noncommercial use, distribution, and reproduction in any medium, provided the original author(s) and source are credited.

\section{References}

Alrababah MA, Alhamad MA, Suwaileh A, Al-Gharaibeh M (2007) Biodiversity of semi-arid Mediterranean grasslands: impact of grazing and afforestation. Appl Veg Sci 10:257-264

Andres C, Ojeda F (2002) Effects of afforestation with pines on woody plant diversity of Mediterranean heathlands in southern Spain. Biodivers Conserv 11:1511-1520

Arrieta S, Suarez F (2006) Scots pine (Pinus sylvestris L.) plantations contribute to the regeneration of holly (Ilex aquifolium L.) in mediterranean central Spain. Eur J Forest Res 125:271-279

Aubin I, Messier C, Bouchard A (2008) Can plantations develop understory biological and physical attributes of naturally regenerated forests? Biol Conserv 141:2461-2476

Barlow J, Gardner TA, Araujo IS, Avila-Pires TC, Bonaldo AB, Costa JE, Esposito MC, Ferreira LV, Hawes J, Hernandez MIM, Hoogmoed MS, Leite RN, Lo-Man-Hung NF, Malcolm JR, Martins MB, Mestre LAM, Miranda-Santos R, Nunes-Gutjahr AL, Overal WL, Parry L, Peters SL, Ribeiro-Junior MA, da Silva MNF, da Silva Motta C, Peres CA (2007a) Quantifying the biodiversity value of tropical primary, secondary, and plantation forests. Proc Natl Acad Sci USA 104:18555-18560

Barlow J, Gardner TA, Ferreira LV, Peres CA (2007b) Litter fall and decomposition in primary, secondary and plantation forests in the Brazilian Amazon. For Ecol Manag 247:91-97

Bashkin MA, Binkley D (1998) Changes in soil carbon following afforestation in Hawaii. Ecology 79:828-833

Bass JOJ (2004) More trees in the tropics. Area 36:19-32

Battles JJ, Shlisky AJ, Barrett RH, Heald RC, Allen-Diaz BH (2001) The effects of forest management on plant species diversity in a Sierran conifer forest. For Ecol Manag 146:211-222

Brockerhoff EG, Ecroyd CE, Langer ER (2001) Biodiversity in New Zealand plantation forests: policy trends, incentives, and the state of our knowledge. NZ J For 46:31-37

Brockerhoff EG, Ecroyd CE, Leckie AC, Kimberley MO (2003) Diversity and succession of adventive and indigenous vascular understorey plants in Pinus radiata plantation forests in New Zealand. For Ecol Manag 185:307-320

Brockerhoff EG, Berndt LA, Jactel H (2005) Role of exotic pine forests in the conservation of the critically endangered New Zealand ground beetle Holcaspis brevicula (Coleoptera: Carabidae). NZ J Ecol 29:37-43

Brockerhoff EG, Jactel H, Parrotta JA, Quine CP, Sayer J (2008) Plantation forests and biodiversity: oxymoron or opportunity? Biodivers Conserv 17:925-951

Brunet J (2007) Plant colonization in heterogeneous landscapes: an 80-year perspective on restoration of broadleaved forest vegetation. J Appl Ecol 44:563-572

Buscardo E, Smith GF, Kelly DL, Freitas H, Iremonger S, Mitchell FJG, O’Donoghue S, McKee AM (2008) The early effects of afforestation on biodiversity of grasslands in Ireland. Biodivers Conserv 17:1057-1072

Cannell MGR (1999) Environmental impacts of forest monocultures: water use, acidification, wildlife conservation, and carbon storage. New Forests 17:239-262

Carnus JM, Parrotta J, Brockerhoff E, Arbez M, Jactel H, Kremer A, Lamb D, O’Hara K, Walters B (2006) Planted forests and biodiversity. J For 104:65-77

Cavelier J, Tobler A (1998) The effect of abandoned plantations of Pinus patula and Cupressus lusitanica on soils and regeneration of a tropical montane rain forest in Colombia. Biodivers Conserv 7:335-347

Cheng C-C, Lai Y-C (2002) Biodiversity in deciduous hardwood and conifer plantations of the Upper Liukuei (Shanping) area. Taiwan J For Sci 17:155-170

Chiarucci A, Dedominicis V (1995) Effects of pine plantations on ultramafic vegetation of central Italy. Israel J Plant Sci 43:7-20 
Chirino E, Bonet A, Bellot J, Sanchez JR (2006) Effects of 30-year-old Aleppo pine plantations on runoff, soil erosion, and plant diversity in a semi-arid landscape in south eastem Spain. Catena 65:19-29

Cremene C, Groza G, Rakosy L, Schileyko AA, Baur A, Erhardt A, Baur B (2005) Alterations of steppe-like grasslands in Eastern Europe: a threat to regional biodiversity hotspots. Conserv Biol 19:1606-1618

Cusack D, Montagnini F (2004) The role of native species plantations in recovery of understory woody diversity in degraded pasturelands of Costa Rica. For Ecol Manag 188:1-15

Daily GC (1997) Nature's services: societal dependence on natural ecosystems. Island Press, Washington, $\mathrm{DC}$

Duan RY, Wang C, Wang XA, Zhu ZH, Guo H (2009) Differences in plant species diversity between conifer (Pinus tabulaeformis) plantations and natural forests in middle of the Loess plateau. Russ $\mathbf{J}$ Ecol 40:501-509

Duran SM, Kattan GH (2005) A test of the utility of exotic tree plantations for understory birds and food resources in the Colombian Andes. Biotropica 37:129-135

Ecroyd CE, Brockerhoff EG (2005) Floristic changes over 30 years in a Canterbury Plains känuka forest remnant, and comparison with adjacent vegetation types. NZ J Ecol 29:279-290

El-Keblawy A, Ksiksi T (2005) Artificial forests as conservation sites for the native flora of the UAE. For Ecol Manag 213:288-296

Estades CF, Temple SA (1999) Deciduous-forest bird communities in a fragmented landscape dominated by exotic pine plantations. Ecol Appl 9:573-585

Fahy O, Gormally M (1998) A comparison of plant and carabid beetle communities in an Irish oak woodland with a nearby conifer plantation and clearfelled site. For Ecol Manag 110:263-273

FAO (2001) Global forests resource assessment 2000. FAO, Rome

FAO (2006) Global forests resource assessment 2005: progress towards sustainable forest management. Report No. 147, FAO, Rome

Farley KA (2007) Grasslands to tree plantations: forest transition in the Andes of Ecuador. Ann Assoc Am Geogr 97:755-771

Farley KA, Kelly EF, Hofstede RGM (2004) Soil organic carbon and water retention following conversion of grasslands to pine plantations in the Ecuadorian Andes. Ecosystems 7:729-739

Farley KA, Jobbagy EG, Jackson RB (2005) Effects of afforestation on water yield: a global synthesis with implications for policy. Glob Chang Biol 11:1565-1576

Farley KA, Pineiro G, Palmer SM, Jobbagy EG, Jackson RB (2008) Stream acidification and base cation losses with grassland afforestation. Water Resour Res 44. doi:10.1029/2007WR006659

Felton A, Knight E, Wood J, Zammit C, Lindenmayer D (2010) A meta-analysis of fauna and flora species richness and abundance in plantations and pasture lands. Biol Conserv 143:545-554

Freemark KE, Boutin C, Keddy CJ (2002) Importance of farmland habitats for conservation of plant species. Conserv Biol 16:399-412

Geldenhuys CJ (1997) Native forest regeneration in pine and eucalypt plantations in Northern Province, South Africa. For Ecol Manag 99:101-115

Goldman RL, Goldstein LP, Daily GC (2008) Assessing the conservation value of a human-dominated island landscape: plant diversity in Hawaii. Biodivers Conserv 17:1765-1781

Gomez-Aparicio L, Zavala MA, Bonet FJ, Zamora R (2009) Are pine plantations valid tools for restoring Mediterranean forests? An assessment along abiotic and biotic gradients. Ecol Appl 19:2124-2141

Gonzales RS, Nakashizuka T (2010) Broad-leaf species composition in Cryptomeria japonica plantations with respect to distance from natural forest. For Ecol Manag 259:2133-2140

Guo LB, Gifford RM (2002) Soil carbon stocks and land use change: a meta analysis. Glob Chang Biol $8: 345-360$

Hartley MJ (2002) Rationale and methods for conserving biodiversity in plantation forests. For Ecol Manag 155:81-95

Hecht SB, Kandel S, Gomes I, Cuellar N, Rosa H (2006) Globalization, forest resurgence, and environmental politics in El Salvador. World Dev 34:308-323

Herault B, Bouxin G, Thoen D (2004) Comparison of the regeneration patterns of woody species between Norway spruce plantations and deciduous forests on alluvial soils. Belg J Bot 137:36-46

Hobbs R, Catling PC, Wombey JC, Clayton M, Atkins L, Reid A (2003) Faunal use of bluegum (Eucalyptus globulus) plantations in southwestern Australia. Agrofor Syst 58:195-212

Humphrey JW (2005) Benefits to biodiversity from developing old-growth conditions in British upland spruce plantations: a review and recommendations. Forestry 78:33-53

Humphrey JW, Hawes C, Peace AJ, Ferris-Kaan R, Jukes MR (1999) Relationships between insect diversity and habitat characteristics in plantation forests. For Ecol Manag 113:11-21 
Igboanugo ABI, Omijeh JE, Adegbehin JO (1990) Pasture floristic composition in different eucalyptus species plantations in some parts of Northern Guinea Savanna Zone of Nigeria. Agrofor Syst 12:257-268

Ito S, Nakayama R, Buckley GP (2004) Effects of previous land-use on plant species diversity in seminatural and plantation forests in a warm-temperate region in southeastern Kyushu, Japan. For Ecol Manag 196:213-225

Kanowski J, Catterall CP, Wardell-Johnson GW, Proctor H, Reis T (2003) Development of forest structure on cleared rainforest land in eastern Australia under different styles of reforestation. For Ecol Manag $183: 265-280$

Koonkhunthod N, Sakurai K, Tanaka S (2007) Composition and diversity of woody regeneration in a 37-year-old teak (Tectona grandis L.) plantation in Northern Thailand. For Ecol Manag 247:246-254

Lamb D (1998) Large-scale ecological restoration of degraded tropical forest lands: the potential role of timber plantations. Restor Ecol 6:271-279

Lambin EF, Meyfroidt P (2010) Land use transitions: socio-ecological feedback versus socio-economic change. Land Use Policy 27:108-118

Lantschner M, Rusch V, Peyrou C (2008) Bird assemblages in pine plantations replacing native ecosystems in NW Patagonia. Biodivers Conserv 17:969-989

Lee EWS, Hau BCH, Corlett RT (2005) Natural regeneration in exotic tree plantations in Hong Kong, China. For Ecol Manag 212:358-366

Lemenih M, Teketay D (2005) Effect of prior land use on the recolonization of native woody species under plantation forests in the highlands of Ethiopia. For Ecol Manag 218:60-73

Lindenmayer DB, Hobbs RJ (2004) Fauna conservation in Australian plantation forests-a review. Biol Conserv 119:151-168

Liu JG, Li SX, Ouyang ZY, Tam C, Chen XD (2008) Ecological and socioeconomic effects of China's policies for ecosystem services. Proc Natl Acad Sci USA 105:9477-9482

Lugo AE (1992) Comparison of tropical tree plantations with secondary forests of similar age. Ecol Monogr 62:1-41

Lugo AE (1997) The apparent paradox of reestablishing species richness on degraded lands with tree monocultures. For Ecol Manag 99:9-19

Maccherini S, De Dominicis V (2003) Germinable soil seed-bank of former grassland converted to coniferous plantation. Ecol Res 18:739-751

Makino S, Goto H, Hasegawa M, Okabe K, Tanaka H, Inoue T, Okochi I (2007) Degradation of longicorn beetle (Coleoptera, Cerambycidae, Disteniidae) fauna caused by conversion from broad-leaved to manmade conifer stands of Cryptomeria japonica (Taxodiaceae) in central Japan. Ecol Res 22:372-381

Marcos JA, Marcos E, Taboada A, Tarrega R (2007) Comparison of community structure and soil characteristics in different aged Pinus sylvestris plantations and a natural pine forest. For Ecol Manag $247: 35-42$

Mather AS (1992) The forest transition. Area 24:367-379

Matthews S, O'Connor R, Plantinga AJ (2002) Quantifying the impacts on biodiversity of policies for carbon sequestration in forests. Ecol Econ 40:71-87

Michelsen A, Lisanework N, Friis I, Holst N (1996) Comparisons of understorey vegetation and soil fertility in plantations and adjacent natural forests in the Ethiopian highlands. J Appl Ecol 33:627-642

Munro NT, Fischer J, Wood J, Lindenmayer DB (2009) Revegetation in agricultural areas: the development of structural complexity and floristic diversity. Ecol Appl 19:1197-1210

Nagaike T (2002) Differences in plant species diversity between conifer (Larix kaempferi) plantations and broad-leaved (Quercus crispula) secondary forests in central Japan. For Ecol Manag 168:111-123

Nagaike T, Hayashi A, Kubo M, Abe M, Arai N (2006) Plant species diversity in a managed forest landscape composed of Larix kaempferi plantations and abandoned coppice forests in central Japan. For Sci 52:324-332

Newmaster SG, Bell FW, Roosenboom CR, Cole HA, Towill WD (2006) Restoration of floral diversity through plantations on abandoned agricultural land. Can J Forest Res 36:1218-1235

Norton DA (1998) Indigenous biodiversity conservation and plantation forestry: options for the future. NZ For 43:34-39

O'Connor TG (2005) Influence of land use on plant community composition and diversity in Highland Sourveld grassland in the southern Drakensberg, South Africa. J Appl Ecol 42:975-988

Ogden J, Braggins J, Stretton K, Anderson S (1997) Plant species richness under Pinus radiata stands on the central North Island Volcanic Plateau, New Zealand. NZ J Ecol 21:17-29

Onaindia M, Mitxelena A (2009) Potential use of pine plantations to restore native forests in a highly fragmented river basin. Ann For Sci 66:8 
Paquette A, Messier C (2010) The role of plantations in managing the world's forests in the Anthropocene. Front Ecol Environ 8:27-34

Paritsis J, Aizen MA (2008) Effects of exotic conifer plantations on the biodiversity of understory plants, epigeal beetles and birds in Nothofagus dombeyi forests. For Ecol Manage 255:1575-1583

Parrotta JA (1995) Influence of overstory composition on understory colonization by native species in plantations on a degraded tropical site. J Veg Sci 6:627-636

Pejchar L, Holl KD, Lockwood JL (2005) Hawaiian honeycreeper home range size varies with habitat: implications for native Acacia koa forestry. Ecol Appl 15:1053-1061

Perz SG (2007) Grand theory and context-specificity in the study of forest dynamics: forest transition theory and other directions. Prof Geogr 59:105-114

Pomeroy D, Dranzoa C (1997) Do tropical plantations of exotic trees in Uganda and Kenya have conservation value for birds? Bird Populations 4:23-36

Powers JS, Haggar JP, Fisher RF (1997) The effect of overstory composition on understory woody regeneration and species richness in 7-year-old plantations in Costa Rica. For Ecol Manag 99:43-54

Proenca VM, Pereira HM, Guilherme J, Vicente L (2010) Plant and bird diversity in natural forests and in native and exotic plantations in NW Portugal. Acta Oecol-Int J Ecol 36:219-226

Putz FE, Redford KH (2010) The importance of defining 'forest': tropical forest degradation, deforestation, long-term phase shifts, and further transitions. Biotropica 42:10-20

Quine CP, Humphrey JW (2010) Plantations of exotic tree species in Britain: irrelevant for biodiversity or novel habitat for native species? Biodivers Conserv 19:1503-1512

Richardson DM, Van Wilgen BW (1986) Effects of 35 years of afforestation with Pinus radiata on the composition of mesic mountain Fynbos near Stellenbosch. S Afr J Bot 52:309-315

Richardson DM, van Wilgen BW (2004) Invasive alien plants in South Africa: how well do we understand the ecological impacts? S Afr J Sci 100:45-52

Richardson DM, Pysek P, Rejmanek M, Barbour MG, Panetta FD, West CJ (2000) Naturalization and invasion of alien plants: concepts and definitions. Divers Distrib 6:93-107

Richardson DM, van Wilgen BW, Nunez MA (2008) Alien conifer invasions in South America: short fuse burning? Biol Invasions 10:573-577

Rudel TK, Coomes OT, Moran E, Achard F, Angelsen A, Xu J, Lamdin E (2005) Forest transitions: towards a global understanding of land use change. Glob Environ Change 15:25-31

Senbeta F, Teketay D, Naslund BA (2002) Native woody species regeneration in exotic tree plantations at Munessa-Shashemene Forest, southern Ethiopia. New Forests 24:131-145

Soo T, Tullus A, Tullus H, Roosaluste E (2009) Floristic diversity responses in young hybrid aspen plantations to land-use history and site preparation treatments. For Ecol Manag 257:858-867

Stephens SS, Wagner MR (2007) Forest plantations and biodiversity: a fresh perspective. J For 105:307-313

Van Dijk A, Keenan RJ (2007) Planted forests and water in perspective. For Ecol Manag 251:1-9

Van Wesenbeeck BK, Van Mourik T, Duivenvoorden JF, Cleef AM (2003) Strong effects of a plantation with Pinus patula on Andean subparamo vegetation: a case study from Colombia. Biol Conserv 114:207-218

Wallace HL, Good JEG (1995) Effects of afforestation on upland plant communities and implications for vegetation management. For Ecol Manag 79:29-46

Yirdaw E (2001) Diversity of naturally-regenerated native woody species in forest plantations in the Ethiopian highlands. New Forests 22:159-177 